\title{
The interferon-induced MxB protein inhibits an early step of HIV-1 infection
}

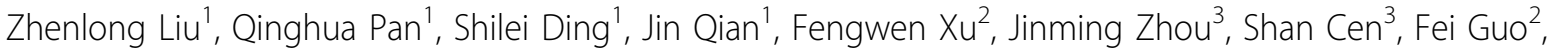 \\ Chen Liang $^{1 *}$
}

From Frontiers of Retrovirology: Complex retroviruses, retroelements and their hosts

Cambridge, UK. 16-18 September 2013

\section{Background}

Interferon protects cells from virus infection by inducing the expression of genes with antiviral activities. One such antiviral gene is $\mathrm{Mx}$ (myxovirus resistance) that was first identified in mice for its protection against influenza virus infection. Humans carry two Mx genes, $\mathrm{MxA}$ and MxB. Although MxA has been reported to inhibit a number of RNA and DNA viruses, the antiviral function of MxB has just begun to be revealed.

\section{Materials and methods}

A human CD4+ T cell line SupT1 was utilized to study the replication of an HIV-1 strain named NL4-3. The MxA or MxB cDNA was cloned into a tetracyclineinducible expression vector and stably transduced into SupT1 cells. The endogenous $\mathrm{MxB}$ was induced with interferon-a2b. MxB-resistant HIV-1 was selected through growing $\mathrm{HIV}-1_{\mathrm{NL} 4-3}$ in $\mathrm{MxB}$-expressing SupT1 cells.

\section{Results}

Ectopic expression of MxB in SupT1 cells, but not MxA, suppressed HIV-1 replication. The inhibition occurred at the integration step. Long-term culture led to the selection of MxB-resistant HIV-1 that carries mutations in viral capsid (CA88) and viral envelope (Env539). A further mutagenesis study revealed that CA88 overcame MxB inhibition; Env539 played a compensatory role by enhancing virus infectivity. Since the CA88 mutation disabled the interaction of HIV-1 capsid with cyclophilin A, a role of cyclophilin A in MxB restriction is hypothesized, which is further supported by the association of $\mathrm{MxB}$ with cyclophilin $\mathrm{A}$ and the loss of $\mathrm{MxB}$ inhibition

${ }^{1}$ Lady Davis Institute, Jewish General Hospital, Montreal, Quebec, Canada Full list of author information is available at the end of the article of HIV-1 as a result of cyclophilin A knockdown or cyclosporine A treatment.

\section{Conclusions}

Taken together, our data suggest that human $\mathrm{MxB}$ protein inhibits HIV-1 DNA integration by a cyclophilin Adependent mechanism.

\section{Authors' details \\ 'Lady Davis Institute, Jewish General Hospital, Montreal, Quebec, Canada. ${ }^{2}$ Institute of Pathogen Biology, Beijing, China. ${ }^{3}$ Institute of Medicinal Biotechnology, Beijing, China.}

Published: 19 September 2013

doi:10.1186/1742-4690-10-S1-P48

Cite this article as: Liu et al:: The interferon-induced MxB protein inhibits an early step of HIV-1 infection. Retrovirology 2013 10(Suppl 1): P48.
Submit your next manuscript to BioMed Central and take full advantage of:

- Convenient online submission

- Thorough peer review

- No space constraints or color figure charges

- Immediate publication on acceptance

- Inclusion in PubMed, CAS, Scopus and Google Scholar

- Research which is freely available for redistribution 